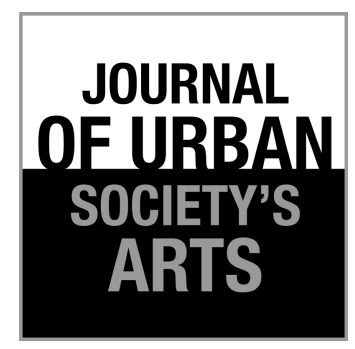

Volume 2 Nomor 2, Oktober 2015: 104-110

\section{Creative by Way of Adaption: Ramayana Relief of Prambanan Temple}

\section{Soeprapto Soedjono}

Jurusan Fotografi, Fakultas Seni Media Rekam, Institut Seni Indonesia Yogyakarta

E-mail: soeprapto.soedjono@yahoo.com; HP: 081578925950

\begin{abstract}
This article aims to discuss the creation of arts based upon the theory of adaptation that had been laid on by Linda Hutcheon in her book called A Theory of Adaptation. The discussion has put emphasis on the elaboration of any visual aesthetics aspects embodied within the Ramayana sculptural program in the narrative relief which is encircling along Prambanan temple inner wall in Kalasan, Yogyakarta. Since the relief's theme is derived from the ancient epic story of Ramayana legend (by Valmiki), it is plausible that the later creative process of the relief work was created through the adaptation theory procedure.
\end{abstract}

Keywords: creative arts, adaptation theory, Prambanan relief, Ramayana

\begin{abstract}
ABSTRAK
Penciptaan Karya Seni dengan proses Adaptasi: Relief Ramayana di Candi Prambanan. Artikel ini membahas tentang proses penciptaan karya seni berdasarkan teori adaptasi sebagaimana yang didiskusikan oleh Linda Hutcheon dalam bukunya yang berjudul: A Theory of Adaptation. Penekanan pembahasan lebih diletakkan pada aspek-aspek estetis visual yang terdapat pada karya seni relief naratif yang mengelilingi sepanjang dinding bagian dalam candi Prambanan di Kalasan, Yogyakarta. Sebagaimana tema relief yang diadaptasi dari ceritera legenda Ramayana yang ditulis oleh Walmiki pada waktu silam, maka proses penciptaan relief tersebut pada masa berikutnya diyakini mengikuti prosedur teori adaptasi tersebut.
\end{abstract}

Kata kunci: cipta seni, teori adaptasi, relief Prambanan, Ramayana

\section{Introduction}

In the creative arts domain, generally there are some variety systems or methods of creating a certain work of art. One of them is dealing with the way how arts are being created through adaptation process from other work/s without losing its sense of creativeness. In this case, I will look at the process of adaptation happened between two works of arts in a different form of disciplines. The former one was in a literary form which had been adapted into visual arts of relief sculptural program.

Every visual artist has to deal with basic problems of visualization in the creative process of images. In particular, such the case may arise when the artist has to transform a certain work of art into another new form of art discipline. The case is done by transforming a literaryartwork into a new form of visual art. From a different point of view, this transformation process can be looked at as the 'act of adaptation' since it involves both (re-) interpretation and then (re-)creation. (Hutcheon, 2006:8). In this process of transformation, (re-)interpretation has been done during the observation through the process of perception by looking out in detail on every parts of the formalistic aspects of the first work adapted either both materialistic aspects and its literary content 
as well. These all gathered information data had been analyzed and interpreted in which later will be used for 're-creation' project. It is plausible also that there will be some additional and alteration processes of necessary things as well. It is coincide with Linda Hutcheon's statement in her book "A Theory of Adaptation" (Routledge,2006) that an adaptation process is "A creative and interpretive act of appropriation/salvaging. "In particular when its process of adaptation is dealing with artworks as one of 'cultural creation' processes as she stated clearly: "Writ large, adaptation includes almost any act of alteration performed upon specific cultural works of the past and dovetails with a general process of cultural creation" (Routledge, 2006:9).

In particular, such the case may arise some problems when the artist has to transform a certain work of art into another new form of art. To cope with these problems some important factors may need to be measured during this particular procedure. The nurturing of the main idea may affect to the development of several important aspects such as, the application of a certain style of aesthetic representation, the use and handling of any particular material, and considering any form of certain message which needs to be delivered to the spectators since we believed that every image is created to be looked at and to serve for carrying the underlying objectives. It is also assumed that these problems of visualization had also been experienced by the Prambanan artists in the past while producing their creative works. In addition, since the images were supposed to be adorned in a respected religious temple, it was

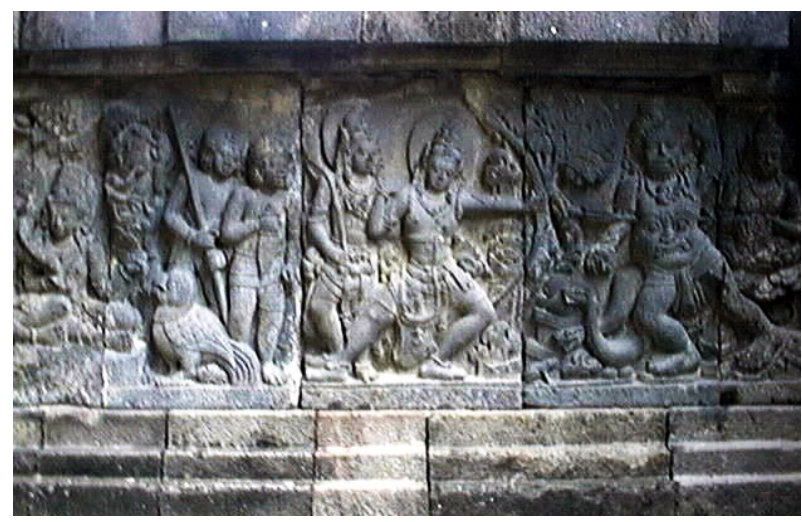

Picture 1. The archery scene when Rama shot the evil Giant with an arrow. also imperative and very appropriate to take into account that some aesthetics considerations has to correspond toward the sacred values embedded in such religious building.

It is the objective of this study to confer the main significant idea of an aesthetic transformation of the epic story of Ramayana which has been adapted into a visual form on the panel relief sculptural programme in Prambanan temple. The discussion will put emphasis on the elaboration of any visual aesthetic qualities embodied in such sculptural works as a verification form of its artistry transformation.

Developing the power of narrative, the Hindus might had been used also some visual storytelling as a way of popularizing their faith. This religious tradition came down over generations in India as well as carried abroad by the Gujarati merchants and Hindus priests to overseas land of Java. Accordingly, the whole story of Ramayana as a literary form of religious-based story should need to be broadened to reach more believers in terms of its content and forms. The adaptation of its nature did not just merely take the form in its inner tradition of the literary per-se but also in

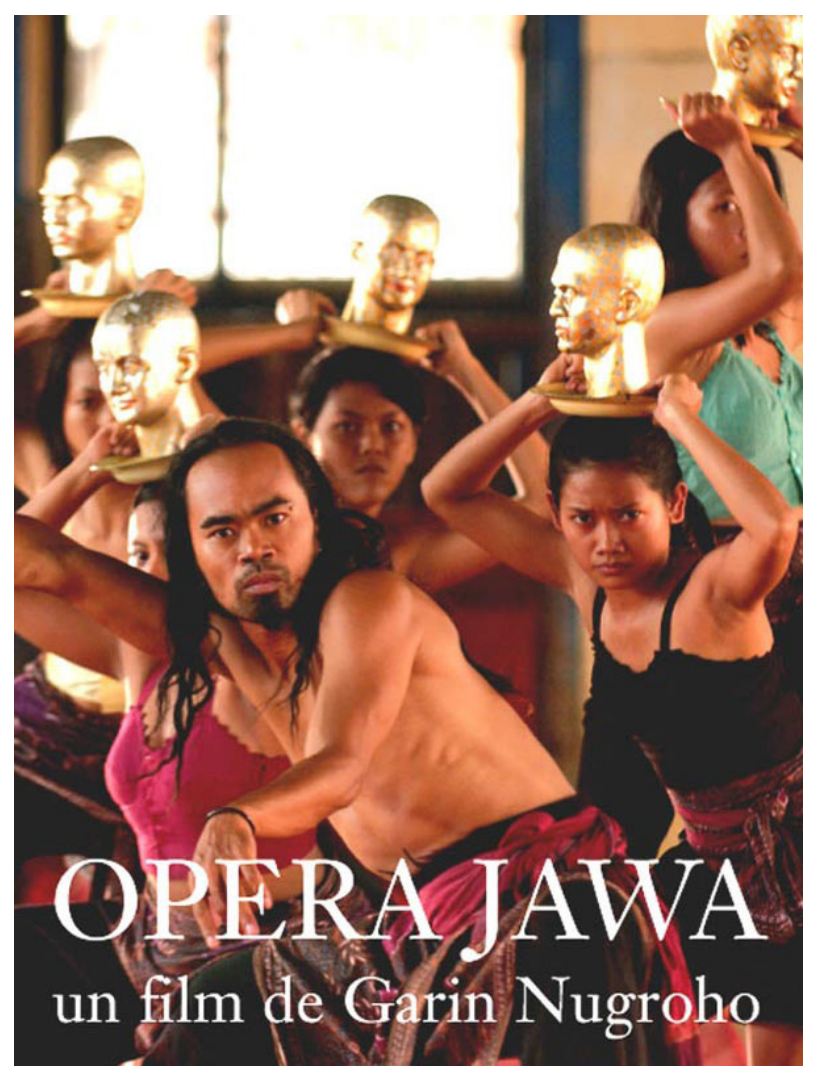

Picture 2. Garin's OPERA JAWA film poster 
another form of disciplines. Such adaptation efforts may need also be based on the notion of written works which were not consumedeasily by the public since they were mostly illiterate people. The variety of adaptation from its 'original' version into its distinctive forms of tradition may correspond to what Tulsidas mentioned in his $16^{\text {th }}$ century Ramcarittnanas that, "Rama is born in countless ways, and there are tens of millions of Ramayanas..." It means that by the passing times such story may had been adapted into many versions and forms for serving any particular functions and needs. In this case, the adaptation of any literary forms of art into such visual aesthetic vocabularies forms were expected tosend the abstract thought of the text across the illiterate audience in easier way due to its visual comprehensionnature.

Tallying the fact of its multi-form of adaptations, this Ramayana story was also made known in a modern audio-visual media as it has been adapted into a television series program that held most Asian watchers spellbound in the 80's and the present times for Indonesian watchers (ANTV). Another version of the story has also been transformed into some forms of movies with different titles and languages. There is one as found in Indonesian movie called 'Opera Jawa'(Requiem from Java) which was produced and directed by Garin Nugroho in 2006. It is an IndonesianAustrian musical movie based on one episode of Ramayana's 'the abduction of Sita'. This film was acclaimed and screened in some international film festivals to commemorate the 250 - year celebration of the birth of Wolfgang Amadeus Mozart. It was commissioned for Peter Sellars's New Crown Hope Festival and featured the traditional Javanese classical music and installation arts in a form of dance with an opera setting.

In addition to its other multi-transformations, this story has also been represented annually in a form of performing art of Wayang-Wongin the outdoor stage of Ramayana Ballet which is held every night during the dry seasons (May through October) and in particular at the full moon within the Prambanan temple complex.

Such performing art forms may also depict the story of Ramayana by way of genre representations to enrich its aesthetics transformation. This notion is obviously present in both the performance of 'wayang' forms (shadow-puppets or Wayang Purwo and live stage performances of Wayang Wong) in Java as well as in the fragmented performance of sacred dance of 'Sang Hyang Dedari' in Kechak dance in the island of Bali. Indeed, these various forms have emphasized their own distinctive vocabulary of aesthetics based upon each genre of aesthetics traditions. Accordingly, all of these forms of genres were adapted from the past Hindus literary traditions of the great epic ofValmiki'sRamayana story.

Thus, the literary tradition of the epic narrative story has been visualized into a variety of visual forms for enhancing the faith of Hindu believers by way of adaptation process which has been led into some aesthetics of transformation values. One of these outcomes of adaptation effort is represented in a meticulous visual form of a reliefsculptural program. A strong affiliation between the quintessence of Hindu's faith with a didactic content and values embedded in the story becomes the main reason for the selection of this story to be depicted and adorned in such religious building. In addition, we also assumed that the selection of Ramayana story had been considered fit and proper to 'enrich' the Hindu believers both in terms of strengthening their faith as well as carrying out the aesthetics purpose as appeared in the Prambanan temple's relief program. In addition, the popularity aspect of the story among the Hindus might also be considered as other determining factor for the depiction of the story as well. Furthermore, this adaptation process will lead into the course of developing the aesthetical values as the rational consequences of such artistry creative efforts.

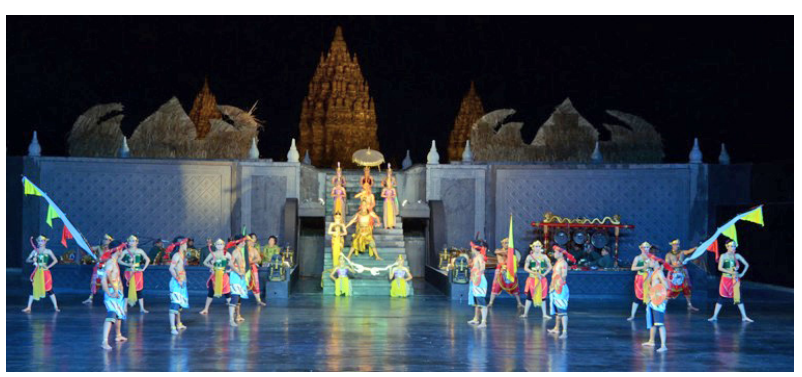

Picture 3. Ramayana Ballet in open air stage 


\section{Aesthetics Transformation Values}

Every transformation process of form in arts is subjected to logical consequences that deal with aesthetical change of values. It is plausible due to each work of art has its own attribute faculties aside from its shape of form and also possesses any embedded qualities that quite distinct to each other. The process of aesthetics transformation in the creating of arts is assumed to be happened in two main stages. These stages might need to be implemented due to: first, the involvement of any decisions pertaining the appropriateness of its literal form with its visual shape of form; Second, technically it was dealing with 'some creative works' made by the artists who create the works. For them, a new form of art becomes a creative medium that based upon the concept of transformation, as stated by Singer (1998:4).by employing a notion of a film production which was based on the existing literary work:

“... - the concept of transformation. Thinker like Eisenstein, Arnheim, and Balazs argue that film becomes an art by transforming what is real instead of merely reproducing or recording it"

We have to keep in mind also that beside of each universal aesthetic quality possession, every form of art also has its own properties that quite distinct from the other form of arts. To cope with these problems some important factors may need to be measured during this particular adaptation procedure.

The notion of transformation medium in different art forms will bring the alteration of their aesthetic values as the consequences of changes in their art form properties. The written and narrative story has been brought into its new form of visual art tradition in a medium of stone panel relief. This process of transformation will also plausibly carry problems of visualization both in the ideational level and in its technical treatment. In more specific ways these problems were dealt with the selection of scenes of the story that need to be depicted and how the selected ones to be visualized. Each particular selected scene which is usually portrayed is based upon the basic interpretation of reading and comprehending the episodes of the story. The process of interpretation related to the cognitive process of making such meaning is understood through various considerations of thought. In this case, the selective scenes have to own at least two qualities of expression and sense of creativeness. And yet, what parts of the story and how those parts supposed to be represented still need to be resolved before making of such decision. Some particular scenes which were selected may derive from any significant moments that dealt with the situation and condition of the dramatic stages of the story. If we refer to the triangular form of dramatic stages of Aristotle, in which every part of the story has to have a unique and significant parts as well as informative moments that need to be comprehended by the beholders. In a way, it was a part of 'how to tell the story' visually in orderly manner. Since the available space is limited for the sculptor/s to work with the ideas of the story, it was reasonable if the selective moment has to be transformed into a 'compact' one. The sculptor might make use of the 'conflated' narrative to deal with the situation of economical space available. This manner of presentation emphasized the importance of the figure to whom reference is repeatedly made(Dehejia, 1997:90).

It is assumed also that such decision has to be made collaboratively among three-key decision makers. Namely, the spiritual leaders as the authority in religious matter has the most power to guide and control the rightness or the decorum values of representations and to correct any discrepancies of the story being depicted; the monarch or the Royal family as the worldly-authority patron to provide financial support and supplies needed during the process of such great project in the kingdom; and the artist/s or sculptor as the key creator for their involvement in an artistic way of planning and handling and to materialize such an enormous project of sacred work of art. They had worked closely on the project with one goal in mind that by doing it the best they can, and hopefully it would surely please their gods by rendering their earthly services for expecting their later rewards in the hereafter. This patronage of religious art is considered to be 
rooted on the concept of spiritual merit which was deep-rooted in Hindus faith of karma, which also states that deeds performed in a present life will surely determine the nature of future birth. Itmight consider a certain way of achieving the deed of good karmaby supporting any efforts of maintaining the construction of religious building.

The implementation of depicting story into a form of relief sculptures in a sacred religious building was not merely for adornment as an aesthetics objectives but also has a function as a tool of strengthening the faith of the believers. This idea is obvious in their treatment of positioning the relief in such a way by letting the pilgrimage to observe it by walking through the passageway of pradhaksina-path to encircle it clockwise through the verandah gallery of the temple. This kind of procedure has also two functioning objectives both secular and sacred objectives. The secular function refers to the idea of common sense how the pilgrim has to read images of the relief correctly and to fully comprehend the visual story in orderly manner. Thus, on a functional level, the presentation of relief-sculptural program is depending on its context of story comprehension. The relief-sculptural images that are subjected to continuous state of transformation and metamorphosis of its former aesthetic form were also need to be deciphered. This notion is coincide to what Leonardo da Vinci was said more than five centuries earlier that, "You must not only believe what you see, you must also understand what you see..." The sacred part is associated with the context notion of religious practice as a way of giving homage to the principal God of the temple

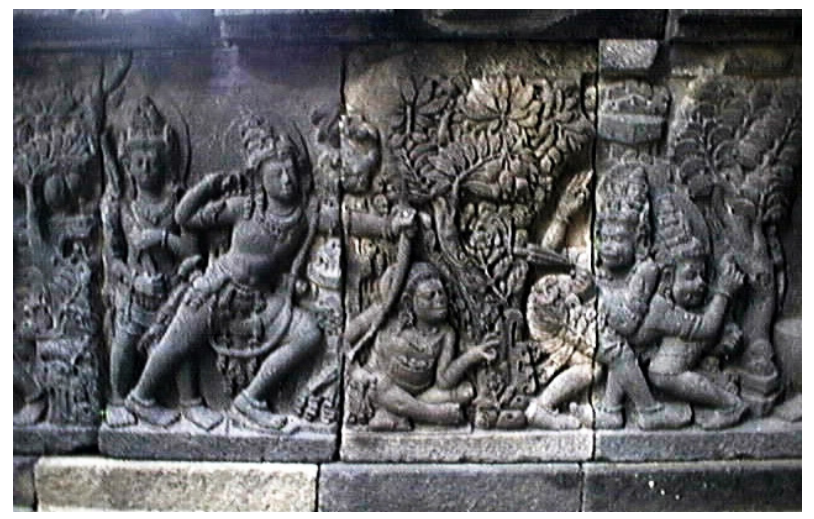

Picture 4. Rama is helping monkey king Sugriva's battle against his brother Subali. which is located in the right side of the verandah gallery. Additionally, the content and meaning of the story may give good examples and lead the faithful toward the ideal ways of living. Thus, the Hindu religious practice intermingles with the secular context of aesthetical values embodied in the elaboration of Ramayana sculptural-relief program in the Prambanan temple. It is plausible due to both aspects are related to serve a certain religiouscommunicative function.

Visually, the sculptural program of the relief which is made of sand stones apparently is representing the whole aspects of universal life of human that surrounded with fauna and flora elements of the time. Their visual presence is adjoined to embellishing the inner wall of the temple as to reflect the aesthetics ideals embodied in the relief. All creatures are represented in realism way of presentation. Such deviation from this manner may be shown in the representation of demonic figures of king Rahwana with his people and some of the monkey Kings which were materialized from the sculptor's indigenous creative interpretation. Demonic faces are so characterized but the other faces as well as gesture of hands, feet, and limbs are remain conventionalized, as they are in most parts were derived from combining Indianizing art tradition with the local indigenous tradition. The whole reliefs in fact, are carved stones that structurally attached as a part of the temple's encircled gallery. Most of the visual stories are represented in the picture plane as a 'three dimensional' painting. The recession size of the pictorial elements are rarely happened which creates a shallow space to the overall scenes.

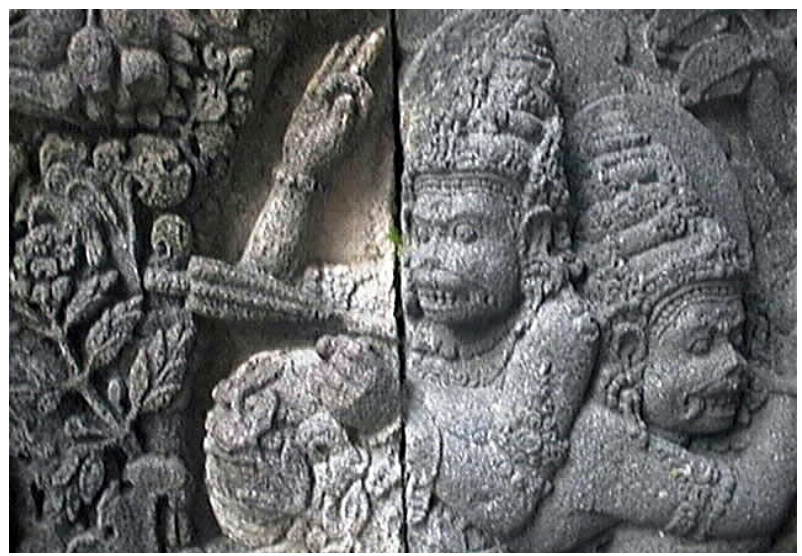

Picture 5. A Detail scene of Prambanan relief. 
Moreover, the spatial depth of scenes was mostly done by the overlapping technique. In this case, a 'perspective' treatment for making a depth visualillusion was a non-issue of appropriateness in the creation of the relief program since the clarity of visual comprehension was the solely main objective.

The technique of its creation consisted of erecting the slab of stones and fixing them as a constructive wall then setting the sculptors to finish them in situ. It is assumed that a group of a lesser-skill sculptors might roughly chisel the stones surface by tracking out the master's sketches design that has been drawn earlier. Later, the master sculptor is to finish the work based on his artistry of personal interpretation and canonical style. Therefore, such a deviation from the unity aspects of the design and its meaning conception of visualization can be avoided. This technique was a common practice for doing such sculptural works which is believed be derived from the Indian artistic school that can be found in most parts of Southeast Asian countries. "One must suppose that in common with all other Indianized courts of Southeast Asia..., Even today similar traditions survive in Java, Bali,..." (Rawson, 1995:89).

The representation of the story in a relief form seems to reflect the sculptors' extra ordinary skill. It is revealed in their creation of tableaux fundamental scenes in which they inserted also sorts of additional illustrious daily scenes and some pictorial elements as to 'bridge' such imaginative notions with a contemporary life as believed were available during the sculptors' time. This treatment is assumed as a way of communicating the story by familiarizing the 'local' subject to the contemporary observers. Accordingly, such visual representation is open for any additional interpretation without sacrificing the essential meaning of the subject. These minor elements included in the scenes may have two purposively functions. First, it may have symbolic connotations to the main subject as the relief was intended to be viewed in two levels of intellectual comprehension. Namely, it was intended for knowledgeable exclusive observers as well as for the illiterate laymen. The other function is to embellish the available space for balancing the composition of relief by fulfilling one of the aesthetics values in the design criteria. For this, it has been visualized in most relief by presenting some species of minor animals, e.g., birds, dogs, squirrel, insects and also some plants, flowers and fruits which were only existed locally. The sculptors not just used their imagination in adapting the story but also had a freedom to adopt such realism ideas from natural surrounding by imitating environment resources available by applying them as their complementary aspect to the main subject. As a matter of fact, a realism handling of human figures might also derive from the local native physiognomy. Especially in the creation of the figure's facial forms which is so characterized distinctively from the faces in the original 'Indianizing-art' style. This kind of treatment is apparent in the figure of Rama's countenance as well. This kind of treatment, again, may also be related to the idea of 'How to minimize the gap of cultural alienation' between the representation of relief with its beholders since the story was adapted from 'far away textual legend'. This fact which was derived from the indigenous creativity of the sculptors is considered as one of the alteration aspects during the adaptation process that might not be available in the original literary text.

All of those visual aesthetics aspects mentioned above are shown as the evidence of the plausible notion within the operating process of the aesthetic transformation values from one recognizable art into another new art form with each distinctive faculties of tradition. As one can relate this idea with the Neo-Platonic view, which was "...well voiced by Pico della Mirandola in Heptaplus (1489), that picture (visual arts) is a form of revelation, an incarnation of the Word"(Wiener, 1973:466).

\section{Conclusion}

The discussion aboveserves the objective of this study to confer the main significant idea of an aesthetic transformation values based upon the 'adaption' theory. The epic story of Ramayana has been adapted into a visual form on the panel relief sculptural programme in Prambanan temple which is shown as evidence of this analysis. The main discussion mainly puts emphasis on the 
elaboration of any visual aesthetic qualities embodied in such sculptural panel relief works as a verification form of its artistry transformation facts due to the aesthetic adaptation procedure. Again, the Ramayana relief sculptural program in the Prambanan temple is work of art based on the notion of adaptation theory which was created in a new medium without lessening both its values of ingenuity andcreativity... "Therefore, an adaptation is a derivation that is not derivative---a work that is second without being secondary"(Hutcheon, 2006:9). Such creative idea/s was done by implementing the religious values from abroad that were combined with the indigenous skillful artistry practice in the process of Indonesian sculptural tradition.

\section{Acknowledgements}

The author acknowledged the ICAPAS 2014 committee for the opportunity to allow me as one of the International Conference for Asia Pacific Arts Studies keynote speakers during its discussion review session. I am also greatly indebted and inspired by the material theory thoroughly discussed by Linda Hutheon in his book $A$ Theory of Adaptation.

\section{Bibliography}

Arnheim, Rudolf. 1969. Visual Thinking. Berkeley:
University of California Press Ltd.

Bloomer, Carolyn M. 1976. Principles of Visual Perception. New York: Van Nostrand Reinhold Company.

Coomaraswamy, Ananda. 1986. Traditional Art and Symbolism. Princeton: Princeton University Press.

Dehejia, Vidya. 1997.Indian Art. London: Phaidon Press Limited.

Fontein, Jan (Ed.).1990. The Sculpture of Indonesia. Washington: Harry N. Abrams.

Hutcheon, Linda. 2006. A Theory of Adaptation. New York: Routledge.

Kempers, Bernard, AJ.1959. Ancient Indonesian Art. Cambridge: Harvard Univ. Press.

Osborn, Harold.1970. Aesthetics and Art Theory. New York: E.P. Dutton \& Co.

Rawson, Philip.1997. The Art of Southeast Asia. London: Thames and Hudson Ltd.

Stutterheim, Willem.1989.Rama-Legends and Rama-Relief in Indonesia. Transl. by: C.D. Paliwal \& R.P. Jain, New Delhi: Indira Gandhi National Centre for the Arts \& Abhinav Publications.

Wiener, Philip P.(Ed.).1973. Dictionary of the History of Ideas: Studies of Selected Pivotal Ideas. Vol. IV. New York: Charles Schribners's Sons.

Zakia, Richard D.1997. Perception and Imaging. Boston: Focal Press. 